\title{
Rapid Land Assessment for Salt Farming Development in the Coastal Area of the Special Region of Yogyakarta, Indonesia
}

\author{
Mukhamad N. Malawani ${ }^{1,}$, Muh Aris Marfai ${ }^{1,2}$, Aldhila G. H. Yoga ${ }^{3}$, Tiara Handayani ${ }^{3}$, Ahmad Cahyadi ${ }^{1}$, \\ Mohammad Isnaini Sadali ${ }^{4}$, Mohamad Zaki Mahasin ${ }^{5}$, Hendratmoro ${ }^{6}$, Suadi ${ }^{7,8}$, and Maryadi Budi Wiyono ${ }^{9}$ \\ ${ }^{1}$ Department of Environmental Geography, Faculty of Geography, Universitas Gadjah Mada, Sekip Utara, Bulaksumur, Yogyakarta 55281, \\ Indonesia \\ ${ }^{2}$ Geospatial Information Agency, Jl. Raya Jakarta - Bogor, Cobinong 16911, Indonesia \\ ${ }^{3}$ Master Program on Planning and Management of Coastal Area and Watershed, Faculty of Geography, Universitas Gadjah Mada, Sekip \\ Utara, Bulaksumur, Yogyakarta 55281, Indonesia \\ ${ }^{4}$ Department of Development Geography, Faculty of Geography, Universitas Gadjah Mada, Sekip Utara, Bulaksumur, Yogyakarta 55281, \\ Indonesia \\ ${ }^{5}$ Directorate General of Sea Space Management, Ministry of Marine Affairs and Fisheries, Jl. Medan Merdeka Timur No. 16, Jakarta \\ 10110, Indonesia \\ ${ }^{6}$ Administration Bureau of Economics and Natural Resources Regional Secretariat, Jl. Ketandan Lor No. 218, Suryatmajan, Yogyakarta \\ 55213 , Indonesia \\ ${ }^{7}$ Department of Fisheries, Faculty of Agriculture, Universitas Gadjah Mada, Jl. Flora Bulaksumur, Yogyakarta 55281, Indonesia \\ ${ }^{8}$ Center for Economic and Public Policy, Universitas Gadjah Mada, Gedung PAU Pasca Sarjana UGM, Jl. Teknika Utara, Yogyakarta 55281, \\ Indonesia \\ ${ }^{9}$ Master Program on Physical Geography, Faculty of Geography, Universitas Gadjah Mada, Sekip Utara, Bulaksumur, Yogyakarta 55281, \\ Indonesia \\ *Corresponding author: malawani@ugm.ac.id
}

\section{KEYWORDS}

Coastal area

Coastal management

Land evaluation

Land suitability

Salt farm

SUBMITTED 8 May 2021

REVISED 30 August 2021

ACCEPTED 8 September 2021
ABSTRACT The government of Indonesia has faced several challenges to its goal of achieving salt selfsufficiency, necessitating the formulation and implementation of strategic steps to increase salt production. Among its islands, Java has a great deal of potential for salt production, as does the Special Region of Yogyakarta, where the government has initiated salt farming development as part of its coastal community empowerment program. This study aimed to (1) evaluate the land suitability of existing salt farms and (2) identify potential sites and make a productivity estimation of salt farms in the Special Region of Yogyakarta, with the broad objective of demonstrating a rapid land assessment for salt farming development using the combination GIS and field survey. The approach was carried out in three phases; i.e., the analyses of land availability, land characteristics, and land recommendations. On-screen digitizing using GIS was applied to identify land availability through several data sources (satellite imagery and a land-use map from the Indonesian topographic map). This process led to the discovery of 19 sites. Land characteristics and land recommendations analysis were carried out in those sites, resulting in multiple land suitability classes, mostly in the S2 class (moderately suitable). Several impediment factors, such as wind, material texture, and temperature, were also identified, along with other obstacles including high tide and tsunami exposure. In terms of supporting the Indonesian salt self-sufficiency program, these results are significant, with salt productivity estimations of the potential sites meeting the target set by the Ministry of Marine Affairs and Fisheries of Indonesia.

(c) The Author(s) 2021. This article is distributed under a Creative Commons Attribution-ShareAlike 4.0 International license.

\section{INTRODUCTION}

The Indonesian government claims to be able to achieve salt self-sufficiency in the near future. This target is challenging because the recent quantity of domestically produced salt has been below that of imported salt (Sukiyah et al. 2017). Despite being an archipelagic country, Indonesia only contributes to $\sim 1 \%$ of the world's salt production (Pusat Riset Kelautan 2021). This may be attributed to the traditional technology used, weather variability, and unsuitable sites for salt farming (Daulay 2019; Kurniawan et al. 2019). These issues have resulted in the target (80-100 tons/ha/harvest) of the Indonesian Ministry of Marine Affairs and Fisheries falling short so far. For this reason, the Indonesian government should formulate and implement strategic management to increase salt production. Most importantly, since not all coastal areas can be utilized for salt cultivation (Mahasin et al. 2020), a fast and efficient means to increase the production target is by arranging coastal land evaluation programs to find suitable sites for salt farm development.

Prior scholars have evaluated land suitability for salt farming development in many regions in Indonesia, such 
as the north coasts of Central Java (Tambunan et al. 2012; Nahar and Taryono 2019), East Java (Kurniawan et al. 2019; Setiawan 2018), Madura (Muhsoni 2012), and Kupang (Nahib et al. 2013). Several approaches with different variables can be used for this purpose. For instance, the physical approach considers physical land variables, such as slopes, soil texture, distance to beaches and rivers, and land cover (Achmadi 2013; Nahar and Taryono 2019). It can be combined with the weather variability or meteorological approach by adding several variables: temperature, solar radiation, humidity, rainfall, and wind speed (Tambunan et al. 2012; Kurniawan et al. 2019). Meanwhile, from the chemical point of view, land suitability can be defined using variables like ammonia, sulfur, and pH (Kurniawan et al. 2019).

Java has enormous potential for salt production. There are more than 10,000 hectares of salt ponds on the island or equal to 0.3 of total salt ponds in the country $(30,786$ ha), where the largest farm area is located in Madura, with $>50 \%$ (Tambunan et al. 2012). With a coastline spanning about $87.12 \mathrm{~km}$ (Marfai et al. 2020), the Special Region of Yogyakarta (SRY) has highly diverse marine activities as sources of regional income, including tourism. The coastal area of SRY has been extensively converted into shrimp ponds in recent years. However, based on information from farmers, in some locations these shrimp ponds have been showing a substantial decline in production. As an alternative solution, the government initiated salt farming development as part of the coastal community empowerment program, including several pilot salt farm projects in SRY's coastal areas such as Samas and Nguyahan. The Nguyahan area is also called by locals as Dadap Ayam. Both locations have distinctive characteristics. Land evaluation on these locations is beneficial as a benchmark for searching the suitable sites for salt farming development in the region. These pilot projects ultimately needs support for accelerating salt production, which can help meets the local and national target. A rapid land assessment is an optimum way to pursue the target quotas. This study aims to identify which areas can accommodate salt farming development, along with their productivity estimation, thus creating the basis for determining salt productivity to support the Indonesian salt self-sufficiency program.

\section{METHODS}

The coastal area of SRY can generally be divided into two different morphological characteristics. The coastal area on the western part has a flat-gently sloping morphology, especially in Bantul and Kulon Progo Regencies. Cliff beach, due to structural-uplifting processes, dominates the coastal area of Gunungkidul Regency in the eastern part. Based on the SRY Geological Map, the western part lies

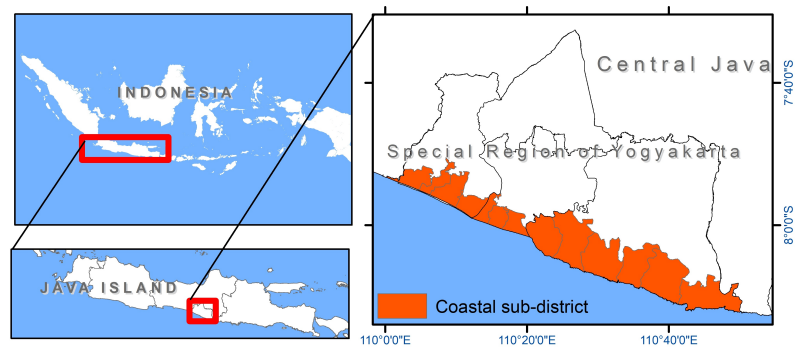

FIGURE 1. The study area involved 13 coastal subdistricts in the Special Region of Yogyakarta, Java, Indonesia. on alluvial deposits, while the eastern part is composed of limestone and calcarenite (Rahardjo et al. 1995). This indicates that the surface materials of the western and eastern parts are different. Administratively, the coast stretches along 13 sub-districts (Figure 1). The coastal populations of SRY work in informal sectors: agriculture, fishery, and tourism. Marine fisheries and coastal tourism in the east (Gunungkidul) are bigger than in the west (Bantul and Kulon Progo; Statistics Indonesia 2020).

The rapid land evaluation analysis for salt farming development in this study was divided into three phases; i.e., land availability, land characteristics, and land recommendations. First, the land availability analysis, also known as land filtering, aimed to determine whether a particular piece of land was available or unavailable for the predetermined purpose. Here, available land can be further analyzed to determine its suitability level or class. In this study, the land availability analysis interpreted and digitized different open landuse types on satellite images and was combined with the RBI map (Peta Rupa Bumi Indonesia, 1:25,000) using the "select by attribute" function in GIS software. Some of the open landuse criteria used in filtering were (1) open land, (2) low vegetation cover, (3) closeness to the beach, and (4) no exposure to tourism activities. This suggestion considered the spatial planning, such as in Bantul (Pansela spatial plan/Rencana Detail Tata Ruang Pansela) and the possibility of landuse type conversion. This process excluded slopes because they do not restrict or create an impediment to salt pond distribution; for instance, the ones in Gunungkidul occupied undulating terraced slopes. Figure 2 shows an example of land filtering

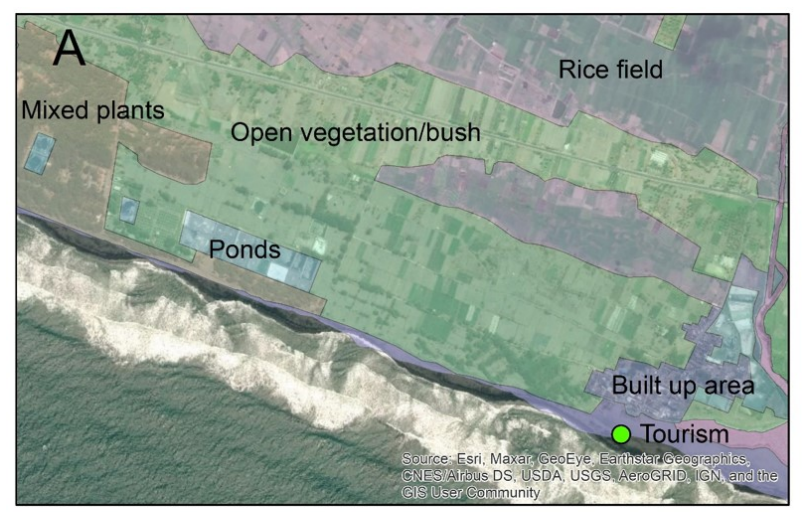

Imagey + Landuse map identification

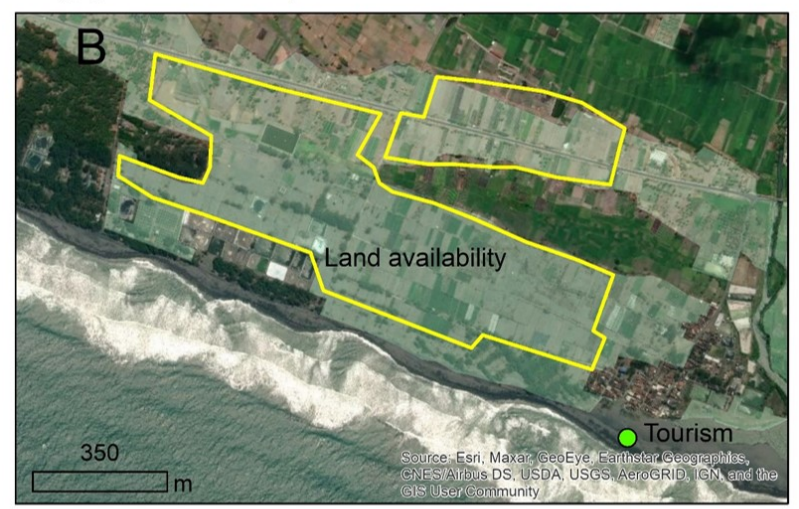

Select attribute from landuse map: open vegetation Land availability digitization

FIGURE 2. Example of the land filtering process from (a) satellite imagery and land-use map as the main data for land availability identification and (b) digitization process into land availability polygon. 
TABLE 1. Variables used in land characteristics analysis and land classification for salt ponds (modified from Kurniawan et al. 2019).

\begin{tabular}{|c|c|c|c|c|}
\hline Variable (class) & S1 (highly suitable) & S2 (moderately suitable) & S3 (slightly suitable) & $\mathrm{N}$ (not suitable) \\
\hline Rain, mm/month (r) & $<10$ & $10-100$ & $100-200$ & $>200$ \\
\hline Material texture (s) & clay & sandy-clay & loamy & silty \\
\hline Humidity (h) & $<45-59$ & $60-74$ & $75-90$ & $>90$ \\
\hline Wind speed, m/s (w) & $>5.7$ & $4.1-57$ & $2.4-4.0$ & $<2.4$ \\
\hline Temperature, ${ }^{\circ} \mathrm{C}(\mathrm{t})$ & $>32$ & $28.5-32$ & $25-28.4$ & $<25$ \\
\hline
\end{tabular}

and land availability delineation for salt ponds.

Second, the land characteristics analysis measured five variables in each available land. This consisted of physical characteristic of the land (i.e., material texture) and weather variation (i.e., rainfall, humidity, wind speed, and temperature). This weather variation described the weather conditions in the study area as it was only measured from ambient or short-term data. The material texture was determined using a textural comparator kit in each sampling site. The rain variable was based on secondary data collected from the nearest weather stations and downloaded from an online data cloud available at https://globalweather.tamu.edu. One of the nearby automatic weather stations (AWS) was in Parangtritis Geomaritime Science Park (PGSP; at 49M 423073x 9114604y). It recorded the last four variables used in the analysis. For areas outside the coverage or far from AWS, the ambient wind speed, temperature, and humidity data were measured using an anemometer. Afterward, each available land was analyzed by comparing its five characteristics with the modified physical-meteorological variables of the salt suitability index, which differentiates land suitability into four classes: S1 (highly suitable), S2 (moderately suitable), S3 (slightly suitable), and N (note suitable), based on Kurniawan et al. (2019), as shown in Table 1.

Third, the land recommendation analysis added a management unit symbol at the end of the land suitability class codes (S1-N; as the main classes). For instance, S1s land refers to a land unit that is highly suitable for salt farming with surface material texture as an impediment factor. With this additional symbol, the overall land classification provided the appropriate recommendation for management practices. For comparative analysis, existing salt ponds in Samas and Nguyahan were also analyzed for their suitability. The salt farmers in Samas and Nguyahan were also interviewed to determine the salt productivity rate, obstacles, and challenges in maintaining salt ponds. Estimated salt productivity calculated using simple calculations based on the results obtained in Samas and Nguyahan. Each of the Samas and Nguyahan salt ponds already has its own productivity rate based on the existing salt pond; i.e., 0.4 and $1.1 \mathrm{~kg} / \mathrm{m}^{2}$ in one harvest, respectively. This value of productivity rate was generated from field observations and interviews with salt farmers (total production $(\mathrm{kg})$ per area of production $\left(\mathrm{m}^{2}\right)$ ). To determine the estimated productivity of the potential locations, the value of the pro- ductivity rate from Samas or Nguyahan was simply multiplied by the area of potential land identified. This result was then multiplied by the area optimization and harvest frequency. We determined the area optimization value at $80 \%$ for all sites, while the harvest frequency depended on the land suitability class, which was estimated to be eight harvests/year for S1, six harvests/year for S2, and four harvests/year for S3. An example of the estimated productivity calculation is shown in Table 2 .

\section{RESULTS}

\subsection{Salt ponds in Samas and Nguyahan}

Samas Beach (Srigading Village, Bantul Regency, SRY) is currently used for fisheries, tourism, shrimp ponds, salt farming, and as a turtle nesting site. Samas was a well-known salt producer in 1950-1980, but over time, it has been showing a decline in salt productivity, and salt farmers have been switching professions to the fisheries and tourism sectors. In 2017, the SRY government planned to revive this economic activity to boost the local economy. However, the program was then realized in early 2020 under the supervision of BUMDES (Badan Usaha Milik Desa, or VillageOwned Enterprises; Figure 3).

The salt production process in Samas consists of siphoning seawater through pipes and accumulating it in a stabilization pond. It also consists of three other ponds; i.e., evaporation, concentration, and crystallization ponds. It uses the salt house method or the tunnel that serves multiple purposes, including as adaptation measures to excessive rain to allow production even during rainy seasons (though lower or only about $30 \%$ of normal production), limited space, and sand-textured soils. The tunnel method can be applied wholly or partly; (i) employs a tunnel-like system in the entire salt production (like in Samas), whereas (ii) tunnels are only used in concentration and crystallization ponds but not in evaporation ponds. At this location, the salt crystallizes from seawater in approximately ten days. Samas produces up to $700 \mathrm{~kg}$ of salt in one cycle or harvest, with a selling price of $3,000 \mathrm{IDR} / \mathrm{kg}$ (price in 2020). Here, natural factors are the primary source of problems faced by salt farmers. For instance, sea waves often destroy suction pipes, particularly during the high tide.

The salt farms in Samas are located in a flat morphology $\left(<2^{\circ}\right)$, with surface materials consisting of mainly sand-

TABLE 2. Example of the calculation of salt productivity per year.

\begin{tabular}{ccccccc}
\hline Site & Area (A) & Productivity rate $\left(\mathrm{kg} / \mathrm{m}^{2}\right)$ & Estimated production (ton/harvest) & Harvest frequency & Optimization & Production/year (ton) \\
\cline { 2 - 7 } & $(1)$ & $(2)$ & $(3)=(1) \times(2) \times 10$ & $(4)$ & $(5)=(3) \times(4) \times(5)$ & 6 \\
\hline KP_1 & 105.6 & 0.4 & 422.4 & 0.8 & 2027.52 \\
\hline
\end{tabular}



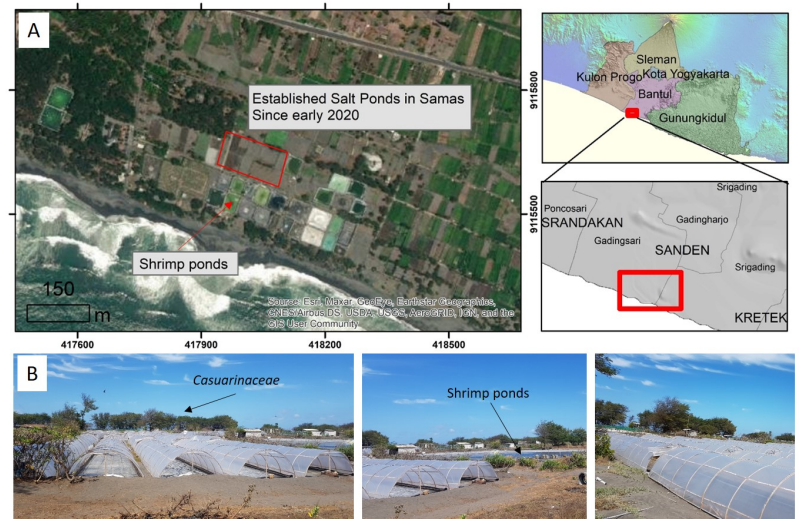

FIGURE 3. Existing salt ponds in Samas, Bantul Regency. (a) Salt ponds are located approximately 150 meters from the shoreline, adjacent to shrimp ponds; (b) Casuarinaceae belt on Samas Beach acting as a wind barrier. Photo courtesy R.A. Muhammad, 2020.

textured soils and some anthropogenic infills for land compaction in several locations. Meteorological features include an ambient temperature of $28.5^{\circ} \mathrm{C}$, wind speed of $2.7 \mathrm{~m} / \mathrm{s}$ at midday, air humidity of $58 \%$, and mean rainfall of below $10 \mathrm{~mm}$ /month (from August-September 2020, as recorded by the AWS at PGSP). Based on these characteristics, the suitability class of existing salt ponds in Samas was S2w, with the wind as the impediment factor. The high density of Casuarinaceae trees forms a wind-breaking structure for the salt ponds located behind this vegetation belt, being planted for coastal protection purposes (Figure 3).

Other well-developed salt farms are on Nguyahan Beach (Kanigoro Village, Gunungkidul Regency, SRY; Figure 4). It is adjacent to the Ngobaran and Baron areas, which are currently utilized as tourist attractions. Salt farm industries have been running since the end of 2018, with a similar form to those of Samas but different in the water extraction process: water is withdrawn vertically instead of horizontally due to the cliff beach. The extracted seawater is then collected in a temporary storage tank, and this is beneficial for anticipating difficulties in water extraction during the high tide. Salt crystallization in Nguyahan takes about seven days and produces up to 700-800 kg per one harvest, with the selling price of $2,500 \mathrm{IDR} / \mathrm{kg}$ (price in 2020). These mean that the salt production is faster, larger, but cheaper than in Samas. According to a report from the Department

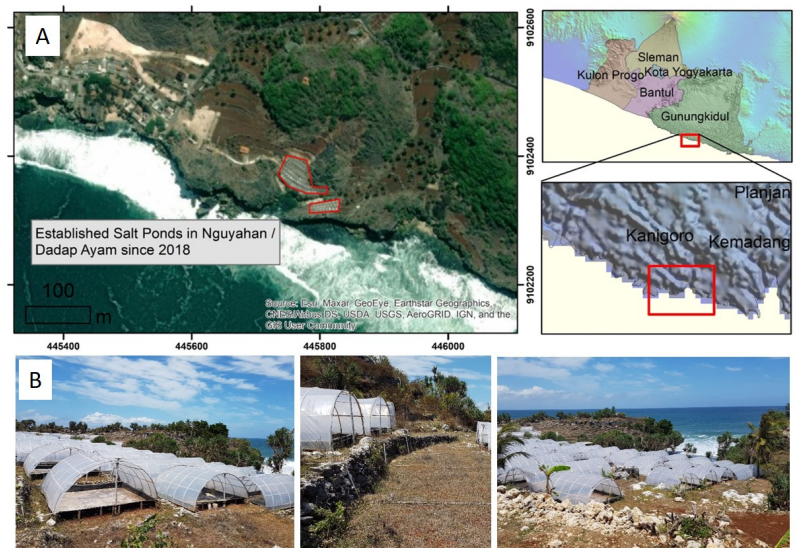

FIGURE 4. Existing salt ponds in Nguyahan, Gunungkidul Regency. (a) Salts ponds are located on a cliff beach, east of tourist attractions; (b) salt ponds are made in terraces to accommodate the gently sloping to undulating terrain. Photo courtesy R.A. Muhammad, 2020. of Marine Affairs and Fisheries of SRY, salt production in Nguyahan reached $186 \mathrm{~kg} /$ month. When correlated with this government report, the figure of $700-800 \mathrm{~kg}$ production per season based on field observations are relatively consistent and not overestimated.

The salt ponds in Nguyahan have different characteristics from the ones in Samas. They are located on undulating slopes at an average elevation of $>15$ masl, with claytextured surface soils. The weather conditions are slightly different from Samas. In this site, the temperatures range between 30 and $31^{\circ} \mathrm{C}$, with a wind speed of $5.5 \mathrm{~m} / \mathrm{s}$, high relative humidity at $68 \%$, and mean rainfall of lower than $10 \mathrm{~mm} / \mathrm{month}$ in dry seasons (rainfall generated from $\mathrm{Gu}-$ nungkidul Regency's conditions). Therefore, the land suitability of these salt farms was determined to be S2, without any significant impediments to their development, including slopes. For management purposes, salt farmers turned the undulating slopes into terraced salt ponds (Figure 4).

\subsection{Potential sites for salt farming development}

Land availability analysis yielded at least 19 potential zones (polygons) distributed in three regencies; i.e., Kulon Progo, Bantul, and Gunungkidul (Table 3). Kulon Progo only has two polygons in Wates and Panjatan Districts, with a total area of 125.8 ha. Most of its coastal area is widely used for dry agriculture and shrimp ponds and as a mangrove area (tourism) on the west. Due to this condition, much of the coastal area in Kulon Progo cannot be selected as a potential site for salt pond development. Bantul has more potential sites with five polygons distributed throughout Sandakan, Sanden, and Kretek, but has a smaller total area (85.4 ha) compared with Kulon Progo. There are similarities in the characteristics of the coastal area in Bantul and Kulon Progo; i.e., the potential location for salt pond development reduces because of the density of tourism sites and shrimp ponds. Gunungkidul has the highest number of potential sites; i.e., 12 polygons, which sum to 41.5 ha. However, it is the narrowest area among the three regencies due to its undulating-hilly topography (karst landform). The distribution of land availability for salt farming development in the SRY coastal area is shown in Figure 5.

The two potential sites for salt farming development in Kulon Progo (KP) are explained below. Polygon KP_1 is located in a swale (a marine landform) with the closest dis-
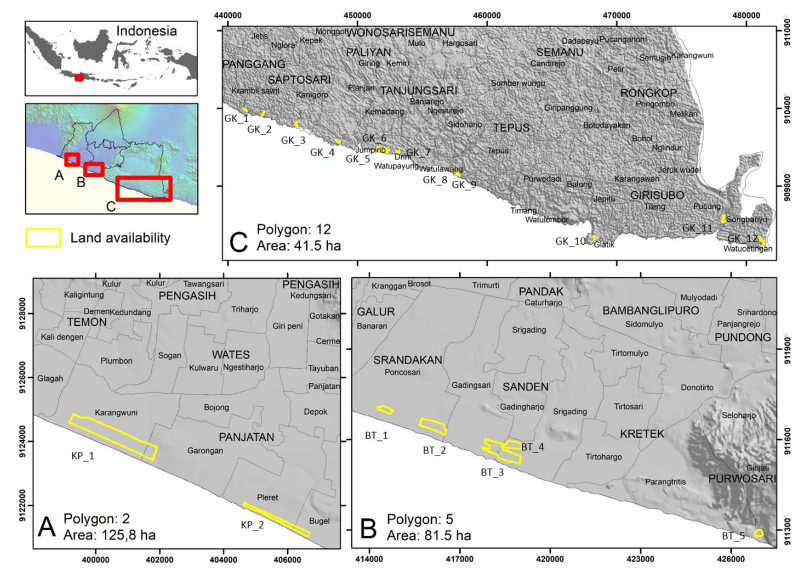

FIGURE 5. Potential land availability for salt farming development in the Special Region of Yogyakarta: (a) Kulon Progo Regency, (b) Bantul Regency, and (c) Gunungkidul Regency. The detailed location of potential sites are presented in the Supplementary Material. 
tance of $75 \mathrm{~m}$ to the sea, a flat slope $\left(0.5^{\circ}\right)$, and predominantly sand-textured soils. Based on ambient air measurements, it has a temperature of $29.8^{\circ} \mathrm{C}$, relative humidity of $68 \%$, wind speed at $5.1 \mathrm{~m} / \mathrm{s}$, and mean rainfall of lower than $10 \mathrm{~mm} / \mathrm{month}$ in dry seasons (generalized from the AWS data at PGSP). For these reasons, polygon KP_1 was categorized into $\mathrm{S} 2$ or moderately suitable for salt ponds without any impeding factors. Similarly, polygon KP_2 was classified as S2, except for the wind (wind speed of $3.5 \mathrm{~m} / \mathrm{s}$ ) that created an impediment to salt ponds development. Therefore, a management unit symbol of " $w$ " was added to the class, i.e., S2w or moderately suitable land for salt ponds with wind speed as an impeding factor. Polygon KP_2 has a vegetation belt on the shoreline, creating an obstacle to the wind corridor and, thus, reducing wind speed.

The potential sites for salt farming development in Bantul (BT) and Kulon Progo share some similarities. Polygons BT_1 (Srandakan Beach), BT_2, BT_3, and BT_4 were classified as S2w, meaning that they are moderately suitable for salt farming development with the wind (wind speed of $<1.5$ $\mathrm{m} / \mathrm{s}$ ) as an impeding factor. Polygons BT_1 and BT_2 have temperatures ranging from 30 to $32^{\circ} \mathrm{C}$ and $63 \square 65 \%$ ambient humidities during daylight and are located on a beach ridge composed mainly of sands. Polygons BT_3 and BT_4 are located close to the existing salt ponds in Samas; hence, they have the same suitability class (i.e., S2w). Polygon BT_5 had the smallest land suitability, S3, because of several factors like temperature $\left(27^{\circ} \mathrm{C}\right)$, material texture (loamy), and wind speed $(2.6 \mathrm{~m} / \mathrm{s})$.

Gunungkidul (GK) has 12 potential zones or polygons for salt farming development. These polygons are located on hilly slopes with clay soils, causing salt farmers to flatten the land and form terraces for their salt ponds. Consequently, the maximum area of each pond is approximately limited to $3 \times 3$ meters. The coastal area of Gunungkidul receives somewhat high rainfall during the rainy season but low rain during the dry season $(<10 \mathrm{~mm} /$ month), especially in July, August, and September. The 12 polygons have similar temperatures (in the range of $30 \square 31^{\circ} \mathrm{C}$ ), humidities between 54\% (GK_5) and 68\% (GK_7), and ambient wind speed between $3.7 \mathrm{~m} / \mathrm{s}$ (GK_10) and $6 \mathrm{~m} / \mathrm{s}$ (GK_5). Based on the observed variables, three polygons (GK_1, GK_5, and GK_6) were classified into S1 (highly suitable for salt farming development), with temperature and wind as impeding factors. Other polygons were categorized into S2 (moderately suitable for salt farming development), with the wind as an impeding factor, especially in GK_3 and GK_11.

\section{DISCUSSION}

Potential sites for salt farming development in the Special Region of Yogyakarta (SRY) are mainly at S2 or moderately suitable, with wind and temperature as impediment factors. Impediment factors are crucial to consider in order to conduct strategic planning for optimizing salt production. For instance, in polygons with the wind as an impeding factor, a wind corridor clearance without any obstacles, such as dense vegetation can creates a suitable setting for high salt production. Site management is different when the impediment factor is temperature. To deal with natural factor (temperature), the management should consider using advanced technology, such as geo-membrane that can shorten evaporation time (Suhendra 2016; Guntur et al. 2018). Other management for optimized salt production is the terracing method, especially in undulating-hilly regions like Gunungkidul. This method can be useful for the availability of gradual salt breeding ponds beneficial for increasing salt production (Jaya et al. 2016).

The existing salt farm in Samas and Nguyahan have a similar land suitability class (S2), but Samas is impeded by the wind, while Nguyahan has no impeding factors. Samas has lower salt productivity $\left(0.4 \mathrm{~kg} / \mathrm{m}^{2}\right)$ than Nguyahan $(1.1$ $\left.\mathrm{kg} / \mathrm{m}^{2}\right)$, implying that the impediment factor significantly affects salt productivity. These salt ponds are operated using traditional techniques; hence, introducing some mod-

TABLE 3. Land characteristics and suitability classification of potential sites for salt farms.

\begin{tabular}{|c|c|c|c|c|c|c|c|}
\hline Polygons & Slope (degree) & Material texture & $\begin{array}{l}\text { Rainfall ( } \mathrm{mm} / \text { month } \\
\text { in dry season) }\end{array}$ & Temperature $\left({ }^{\circ} \mathrm{C}\right)$ & Humidity (\%) & Wind $(\mathrm{m} / \mathrm{s})$ & Classification \\
\hline KP_1 & 0.5 & Sandy & $<10$ & 29.8 & 68 & 5.1 & $\mathrm{~S} 2$ \\
\hline KP_2 & 1 & Sandy & $<10$ & 29.4 & 65 & 3.5 & S2w \\
\hline BT_1 & 1.2 & Sandy & $<10$ & 31.6 & 65 & 1.4 & S2w \\
\hline BT_2 & 1 & Sandy & $<10$ & 30.6 & 63 & 1.3 & S2w \\
\hline BT_3 & 1.5 & Sandy & $<10$ & 28.5 & 58 & 2.7 & $\mathrm{~S} 2 \mathrm{w}$ \\
\hline BT_4 & 1.5 & Sandy & $<10$ & 28.5 & 58 & 2.5 & S2w \\
\hline BT_5 & 1.4 & Loamy & $<10$ & 27 & 65 & 2.6 & S3 \\
\hline GK_1 & $5-10$ & Clay & $<10$ & 31 & 58 & 4.5 & S1tw \\
\hline GK_2 & 8 & Clay & $<10$ & 30 & 60 & 5 & $\mathrm{~S} 2$ \\
\hline GK_3 & 5 & Clay & $<10$ & 30.5 & 61 & 4 & S2w \\
\hline GK_4 & $>10$ & Clay & $<10$ & 31 & 60 & 4.3 & $\mathrm{~S} 2$ \\
\hline GK_5 & 8 & Clay & $<10$ & 31 & 54 & 6 & S1t \\
\hline GK_6 & 8 & Clay & $<10$ & 31 & 55 & 5.8 & S1t \\
\hline GK_7 & 5 & Clay & $<10$ & 30 & 68 & 5 & $\mathrm{~S} 2$ \\
\hline GK_8 & 5 & Clay & $<10$ & 31 & 65 & 4.2 & $\mathrm{~S} 2$ \\
\hline GK_9 & $5-10$ & Clay & $<10$ & 31 & 62 & 4.7 & $\mathrm{~S} 2$ \\
\hline GK_10 & $5-10$ & Clay & $<10$ & 30 & 61 & 3.7 & $\mathrm{~S} 2$ \\
\hline GK_11 & 8 & Clay & $<10$ & 31 & 62 & 4 & $\mathrm{~S} 2 \mathrm{w}$ \\
\hline GK_12 & 8 & Clay & $<10$ & 31 & 65 & 4.6 & S2 \\
\hline
\end{tabular}


ified technology, such as gravity media filter (GMF) and a black HDPE (high-density polyethylene) tarpaulin, can substantially increase salt productivity by up to $70 \%$ (Susanto et al. 2015). Also, it will produce salts that are safe for raw materials and required the Indonesian product standards (SNI No. 4435-2017; Jumaeri et al. 2018).

Information on salt productivity in Samas is useful for estimating salt productivity in both Kulon Progo and Bantul Regencies due to similar coastal typology. Based on the productivity rate in Samas, the potential salt production in Kulon Progo is estimated at 503.2 tons/harvest or equal to $2,415.4$ ton per year. Bantul has a lower productivity estimate, i.e., 341.6 tons/harvest or equal to 1613.4 ton per year. Based on the productivity rate of Nguyahan, the potential salt production in Gunungkidul is estimated at up to 453.5 tons/harvest for area of 41.5 ha or equal to 2,367.2 ton per year. Therefore, salt productivity potential in SRY using this estimation is estimated to reach 1,301.3 tons/harvest or equal to 6,396 tons/year. This value is generated from the total estimated salt production in Kulon Progo, Bantul, and Gunungkidul, which has considered the harvesting frequency and optimization of area utilization (Table 4). However, this figure is still lower than salt production in the Lamongan Regency; i.e., 30,000 tons/year from 350-ha of salt ponds (Guntur et al. 2018). Nevertheless, with an estimated productivity of 1,301.3 tons/harvest, the potential salt production in SRY meets the productivity target set by the Indonesian Ministry of Marine Affairs and Fisheries, although it only contributes about $1.2 \%$ of the national traditional salt production.

SRY's coastal areas have mostly been developed as tourist attractions, creating an issue of land conversion for salt pond development. In Bantul Regency, several locations also attributed for coastal conservation due to active sand transport in the sand dune field (Malawani et al. 2019a; Sunarto et al. 2018). Various supporting programs such as socialization, training, and mentoring are useful for shortening the conversion processes. The introduction of new technologies for the small-scale salt industry can also speed up salt diversification (Suwasono et al. 2015). Other challenges of salt farming development in this region include coastal erosion and tsunamis. Coastal erosion poses threats to salt farm in Samas, especially during high tide seasons. It leads to shoreline retreat and is likely to destroy the suction pipe (Figure 6). These threats possibly disturbed salt production processes and the resulting productivity might not be optimal: decreasing the frequency of harvest (Mahasin et al. 2020).

In Bantul Regency, the shoreline is highly dynamic and has been retreating as far as $0.9 \mathrm{~m}$ /year in the last decade (Widianto and Damen 2014). High tides can be more severe during extreme weather seasons like cyclones, causing waves to surge landward and reach $50-70 \mathrm{~m}$ from the shoreline (Malawani et al. 2019b). In tsunami hazard modeling, concomitant seawater inundation in Bantul and Kulon Progo shows extensive destructive impacts. Based on the worst scenario, tsunami waves in Bantul Regency can propagate $>500 \mathrm{~m}$ from the shoreline (Putri et al. 2019). However, salt ponds in Gunungkidul are safer from high tides and tsunami hazards than those in Bantul and Kulon Progo. The coastal typology of Gunungkidul is dominated by structurally shaped coast and wave erosion coast-cliff (Marfai et al. 2013), meaning that high tides and tsunamis will have no direct effect on salt ponds. These potential problems and challenges in the salt farming development in SRY can be minimized by enforcing relevant governmental regulations like coastal zone planning on a detailed scale (Rencana Detail Tata Ruang, or RTDR). The formulation of policies related to the implementation of salt governance will help to ensure the social and economic security of salt farmers (Fauzin 2021). For instance, special RTDR map for coastal area such as in Bantul Regency (RTDR Pansela) can be repli-

TABLE 4. Estimated salt productivity of the potential sites in SRY.

\begin{tabular}{lrrcccc}
\hline Polygons & Area (ha) & Productivity rate $\left(\mathrm{kg} / \mathrm{m}^{2}\right)$ & $\begin{array}{c}\text { Estimated production } \\
\text { (ton/harvest) }\end{array}$ & $\begin{array}{c}\text { Harvest } \\
\text { frequency }\end{array}$ & Optimization (\%) & Production per year (ton) \\
\hline KP_1 & 105.6 & 0.4 & 422.4 & 6 & 80 & 2027.5 \\
KP_2 & 20.2 & 0.4 & 80.8 & 6 & 80 & 387.8 \\
BT_1 & 6.9 & 0.4 & 27.6 & 6 & 80 & 132.5 \\
BT_2 & 22.7 & 0.4 & 90.8 & 6 & 80 & 435.8 \\
BT_3 & 40.3 & 0.4 & 161.2 & 6 & 80 & 773.8 \\
BT_4 & 11.4 & 0.4 & 45.6 & 6 & 80 & 528.9 \\
BT_5 & 4.1 & 0.4 & 16.4 & 4 & 80 & 66.9 \\
GK_1 & 1.9 & 1.1 & 20.9 & 4 & 80 & 79.2 \\
GK_2 & 1.5 & 1.1 & 16.5 & 6 & 80 & 121.4 \\
GK_3 & 2.3 & 1.1 & 25.3 & 6 & 80 & 121.4 \\
GK_4 & 2.3 & 1.1 & 25.3 & 6 & 80 & 640.6 \\
GK_5 & 9.1 & 1.1 & 100.1 & 8 & 80 & 197.1 \\
GK_6 & 2.8 & 1.1 & 30.8 & 8 & 80 & 110.9 \\
GK_7 & 2.1 & 1.1 & 23.1 & 6 & 80 & 89.8 \\
GK_8 & 1.7 & 1.1 & 18.7 & 6 & 80 & 169.0 \\
GK_9 & 3.2 & 1.1 & 35.2 & 6 & 80 & 100.3 \\
GK_10 & 1.9 & 1.1 & 20.9 & 6 & 80 & 401.3 \\
GK_11 & 7.6 & 1.1 & 83.6 & 6 & 80 & 269.3 \\
GK_12 & 5.1 & 1.1 & 56.1 & 6 & 80 & 6369.0 \\
\hline Total & & 1301.3 & & & \\
\hline
\end{tabular}



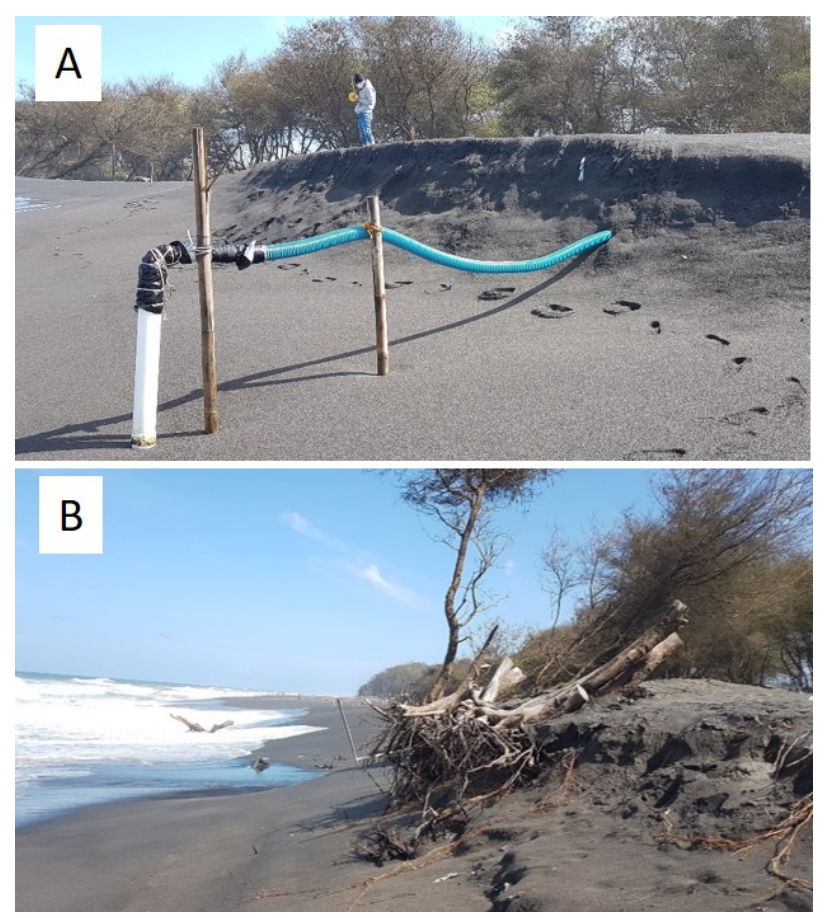

FIGURE 6. (a) Damaged suction pipe connecting seawater to salt ponds in Samas, and (b) shoreline retreat affecting the Causarinacea belt in Srandakan, Bantul Regency. Photo courtesy R.A. Muhammad, 2020.

cated in other regencies to support salt pond development.

\section{CONCLUSIONS}

Our findings demonstrated that rapid assessment can provide spatial data of land suitability and estimated production rate. The assessment method conducted in this study, both the phases and parameters used, is highly suggested for a rapid study of the land suitability for salt farming planning and development. The coastal area along the Special Region of Yogyakarta has potential for salt farm development. Based on land characteristics and weather conditions, 19 potential sites distributed in three regencies are mainly S2 or moderately suitable for salt farming development. The salt productivity in the coastal area of SRY was estimated at 1,301 tons/harvest or equal to 6,369 tons/year, which meets the salt production target set by the Indonesian Ministry of Marine Affairs and Fisheries. However, several salt production optimizations are required, including the management of impediment factors, technological enhancement, and the enforcement of government regulations such as detailed coastal landuse planning.

\section{ACKNOWLEDGMENTS}

This study was partially supported by Institutional Cooperation Research Grants for Community Services, MPPDAS, Faculty of Geography, Universitas Gadjah Mada, and the Center for Economic and Public Policy Studies (PSEKP UGM). The authors would like to thank the anonymous reviewers for their constructive comments. Thanks to Riha Ali Muhammad and Hatfan Muhammad for their assistance during the field survey.

\section{AUTHORS' CONTRIBUTIONS}

MNM, MAM, AC, and MIS designed the research. MNM, AGHY, and TH wrote the original manuscript. MAM and
MBW improved the manuscript. MZM, HH, and SS supplied data and discussion.

\section{COMPETING INTERESTS}

The authors declare no competing interests.

\section{REFERENCES}

Achmadi. 2013. Study for development of conventional salt pond center in the south coast region of Sampang Regency, East Java Province (Kajian pengembangan sentra tambak garam rakyat di kawasan pesisir Selatan Kabupaten Sampang Provinsi Jawa Timur) [dissertation]. [Bogor]: IPB University. http://repository.ipb .ac.id/handle/123456789/63091.

Daulay AN. 2019. Analisis pasar komoditi garam di Indonesia [Salt commodity market analysis in Indonesia]. IAlMasharif: lmu Ekonomi dan Keislaman. 7(2):176-191. doi: 10.24952/masharif.v7i2.2179.

Fauzin F. 2021. Pengaturan impor pangan negara Indonesia yang berbasis pada kedaulatan pangan [Regulation of Indonesian food imports based on food sovereignty]. Pamator J. 14(1):1-9. doi:10.21107/pamator.v14i1.10497.

Guntur G, Jaziri AA, Prihanto AA, Arisandi DM, Kurniawan A. 2018. Development of salt production technology using prism greenhouse method. IOP Conf Ser: Earth Environ Sci. 106:12082. doi:10.1088/1755-1315/106/1/0120 82.

Jaya NTSP, Hartati R, Widianingsih W. 2016. Produksi garam dan bittern di tambak garam [Salt and bittern production in salt ponds]. Jurnal Kelautan Tropis. 19(1):43. doi:10.14710/jkt.v19i1.599.

Jumaeri, Sulistyaningsih T, Alighiri D. 2018. Quality monitoring of salt produced in Indonesia through seawater evaporation on HDPE geomembrane lined ponds. J Phys: Conf Ser. 983:12166. doi:10.1088/1742-6596/98 3/1/012166.

Kurniawan A, Jaziri AA, Amin AA, Salamah LN. 2019. Indeks kesesuaian garam (Ikg) untuk menentukan kesesuaian lokasi produksi garam; analisis lokasi produksi garam di Kabupaten Tuban dan Kabupaten Probolinggo [Salt suitability index (Ikg) to determine the suitability of salt production sites; analysis of salt production locations in Tuban and Probolinggo Regencies]. JFMR - J Fish Mar Res. 3(2):119-127. doi:10.21776/ub.jfmr.2019.003.02.14.

Mahasin MZ, Rochwulaningsih Y, Sulistiyono ST. 2020. Coastal ecosystem as salt production centre in Indonesia. E3S Web Conf. 202:07042. doi:10.1051/e3sconf/20 2020207042.

Malawani M, Mardiatno D, Sunarto. 2019a. Sand transport characterization on the foredune area of Parangtritis, Indonesia. E3S Web Conf. 76:04007. doi:10.1051/e3sc onf $/ 20197604007$.

Malawani MN, Marfai MA, Hadmoko DS, Putra MD, Setyawan N, Prakosa SH, Mardiyanto, Widagdo B, Yoga AGH, Sasongko MHD, Handayani T. 2019b. Respons pantai terhadap gelombang pasang akibat siklon di Daerah Istimewa Yogyakarta [Shore response due to tidal wave triggered by cyclone in Daerah Istimewa Yogyakarta]. Majalah Ilmiah Globe. 21(2):87-94. doi:10.248 95/MIG.2019.21-2.953.

Marfai MA, Cahyadi A, Anggraini DF. 2013. Tipologi, dinamika, dan potensi bencana di pesisir kawasan karst Kabupaten Gunungkidul [Typology, dynamics, and 
potential disasters in the coastal karst area of $\mathrm{Gu}^{-}$ nungkidul Regency]. Forum Geografi. 27(2):147-158. doi: 10.23917/forgeo.v27i2.2373.

Marfai MA, Fatchurohman H, Cahyadi A. 2020. Pesisir Gunungkidul [Gunungkidul coast]. Yogyakarta: Gadjah Mada University Press.

Muhsoni FF. 2012. Kesesuaian lahan tambak garam menggunakan sistem informasi geografis di Kabupaten Sampang [The suitability of salt pond land using geographic information systems in Sampang Regency]. Seminar Nasional Kedaulatan Pangan dan Energi 2012; Madura, Indonesia. p. 44-52.

Nahar MS, Taryono. 2019. Analysis of salt farm suitability in coastal area of Kecamatan Trangkil Kabupaten Pati (Analisis Kesesuaian Tambak Garam di Pesisir Kecamatan Trangkil Kabupaten Pati) [dissertation]. [Surakarta]: Universitas Muhammadiyah Surakarta. ht tp://eprints.ums.ac.id/id/eprint/78309.

Nahib I, Suwarno Y, Prihanto Y. 2013. Analysis of the potential salt pond by using interpretation remote sensing image approach: case study at Kupang Regency coastal area. Jurnal Globe. 15(2):107-113.

Pusat Riset Kelautan. 2021. Prediksi produksi garam nasional 2021. http://pusriskel.litbang.kkp.go.id/in dex.php/en/publikasi/prediksi-produksi-garam.

Putri RF, Wibirama S, Mardiatno D, Giyarsih SR, Sri Sumantyo JT. 2019. Investigating a conservation area based on Tsunami hazard mapping in landuse planning of Sand Dune Parangtritis area, Yogyakarta, Indonesia. Proc Pak Acad Sci: Part B. 56(2):15-26.

Rahardjo W, Sukandarrumidi, Rosli HMD. 1995. Geological map of the Yogyakarta sheet, Jawa, 1:100,000 scale.

Setiawan W. 2018. Studi kesesuaian wilayah pesisir sebagai lahan tambak garam di Kecamatan Palang Kabupaten Tuban [Study of the suitability of coastal areas as salt ponds in Palang District, Tuban Regency]. Prosiding SNasPPM. p. 215-220. http://prosiding.unirow.ac.id/i ndex.php/SNasPPM/article/view/212.
Statistics Indonesia. 2020. Yogyakarta Province in figures. Yogyakarta: Statistics of Yogyakarta Special Region.

Suhendra A. 2016. Increasing the productivity of salt through HDPE geomembrane - Indonesian case history in salt evaporation pond. Electron J Geotech Eng. 21:4273-4280. http://www.ejge.com/2016/Ppr2016. 0363ma.pdf.

Sukiyah E, Isnaniawardhani, Sudradjat A, Muhamadsyah F. 2017. The salt potentials in Indonesia. J Geol Sci Appl Geol. 2(1):28-33.

Sunarto, Malawani M, Fatchurohman H, Cahyadi A. 2018. Identification of landscape disturbance in the Parangtritis sand dune area for sustainable environment. IOP Conf Ser: Earth Environ Sci. 179(012030). doi:10.1088/1755-1315/179/1/012030.

Susanto H, Rokhati N, Santosa GW. 2015. Development of traditional salt production process for improving product quantity and quality in Jepara District, Central Java, Indonesia. Procedia Environ Sci. 23:175-178. doi:10.1016/j.proenv.2015.01.027.

Suwasono B, Munazid A, Poerwowidagdo SJ, Najid A. 2015. Strategic planning for capacity building production and salt farmer in region of Surabaya City East Java Indonesian. Am Sci Res J Eng Technol Sci. 12(1):53-65. http://asrjetsjournal.org/index.php/American_S cientific_Journal/article/download/631/511.

Tambunan RB, Hariyadi H, Santoso A. 2012. Evaluasi kesesuaian tambak garam ditinjau dari aspek fisik di Kecamatan Juwana Kabupaten Pati [Evaluation of the suitability of salt ponds in terms of physical aspects in Juwana District, Pati Regency]. J Mar Res. 1(2):181-187. doi:10.14710/jmr.v1i2.2036.

Widianto A, Damen M. 2014. Determination of coastal belt in the disaster prone area: a case study in the coastal area of Bantul Regency, Yogyakarta, Indonesia. Indones J Geogr. 46(2):125-137. doi:10.22146/ijg.5782. 